\title{
Measurement of gluten using a monoclonal antibody to a coeliac toxic peptide of A gliadin
}

\author{
H J Ellis, S Rosen-Bronson, N O’Reilly, P J Ciclitira
}

\begin{abstract}
Background-Future European Community regulations will require a sensitive and specific assay for measurement of coeliac toxic gluten proteins in foods marketed as gluten-free. To avoid spurious cross reactions with non-toxic proteins, specific antibodies and target antigens are required. A synthetic 19 amino acid peptide of A gliadin has been shown to cause deterioration in the morphology of small intestinal biopsy specimens of coeliac patients in remission.

Aims-To develop an assay for detection of gluten in foods, based on measurement of a known toxic peptide.

Methods-A monoclonal antibody raised against the toxic $A$ gliadin peptide, with a polyclonal anti-unfractionated gliadin capture antibody, was used to develop a double sandwich enzyme linked immunosorbent assay (ELISA) for the measurement of gluten in foods.

Results-Standard curves for gliadin and for rye, barley, and oat prolamins were produced. The sensitivity of the assay was $4 \mathrm{ng} / \mathrm{ml}$ of gliadin, $500 \mathrm{ng} / \mathrm{ml}$ for rye prolamins, and $1000 \mathrm{ng} / \mathrm{ml}$ for oat and barley prolamins. The assay could detect gluten in cooked foods, although at reduced sensitivity. Prolamins from coeliac non-toxic rice, maize, millet, and sorghum did not cross react in the assay. A variety of commercially available glutenfree foods were analysed; small quantities of gluten were detected in some products. Conclusion-The assay may form the basis of a sensitive method for measurement of gluten in foods for consumption by patients with coeliac disease. (Gut 1998;43:190-195)
\end{abstract}

Keywords: gluten; gliadin; prolamin; coeliac disease; monoclonal antibodies

Georgetown

University, USA

S Rosen-Bronson

Peptide Synthesis Laboratory, ICRF, Lincoln's Inn Field, London, UK

N O'Reilly

Correspondence to: Professor P J Ciclitira, Gastroenterology Unit, UMDS, The Rayne Institute, St Thomas's Hospital, Lambeth Palace Road, London SE1 7EH, UK.

Accepted for publication 18 February 1998 complicate coeliac disease. ${ }^{3}$ UK regulations state that foods labelled as gluten-free must contain less than $0.3 \%$ of protein derived from wheat, rye, barley, and oats, determined by
Kjeldahl nitrogen. ${ }^{4}$ The European Community will require measurement of the wheat prolamin, gliadin, rather than all wheat derived proteins, which include albumins, globulins, and starch granule proteins. ${ }^{2}$ The permissible level is likely to be set at $10 \mathrm{mg}$ gliadin $/ 100 \mathrm{~g}$ product. However, progress has been hampered by lack of a suitable assay. The assay should be accurate, robust, simple, and capable of detecting all prolamins toxic to coeliac patients, but should not cross react with coeliac non-toxic cereals, such as maize. Polyclonal antibody based assays suffer a lack of specificity ${ }^{5}$; monoclonal based systems allow quantitation of coeliac toxic epitopes.

A 19 amino acid peptide of A gliadin (sequence: LGQQQPFPPQQPYPQPQPF) caused morphometric and cellular changes in the small intestinal mucosa of coeliac patients in remission. ${ }^{7}$ In this study we raised monoclonal antibodies against this 19-mer peptide to establish an enzyme linked immunosorbent assay (ELISA) for measurement of those cereal prolamins which exacerbate coeliac disease.

Prolamins in cooked foods are difficult to measure due to the low extractability of all but the minor low sulphur ( $\omega$ gliadin) component. ${ }^{8}$ Pretreatment of cooked foods with a reducing agent to break interchain disulphide bonds formed during cooking would render soluble the major $\alpha$ and $\gamma$ (sulphur containing) gliadins. We therefore assessed the effect of reducing agents in our assay.

\section{Methods}

PEPTIDE SYNTHESIS, AND POLYCLONAL AND MONOCLONAL ANTIBODY PRODUCTION

Peptide synthesis was performed as described previously. ${ }^{7}$ In addition to native peptide, we produced alanine point substituted analogues of the coeliac activating 19-mer, which comprises amino acids 31-49 of A gliadin. Amino acids $31,33,36,38,39,41,42,44,46$, and 48 were substituted. These peptides were biotinylated. Polyclonal rabbit antibodies to gliadin and the murine antipeptide monoclonals were produced as previously described. ${ }^{9}$

\section{CONCENTRATION AND PURIFICATION OF}

\section{ANTIBODIES}

The IgG fraction of polyclonal rabbit antigliadin and monoclonal antipeptide antibody PN3, which was of the IgG1 subclass, were purified by $45 \%$ ammonium sulphate precipitation and made up to 0.3 and 0.1 of their original volumes respectively. 


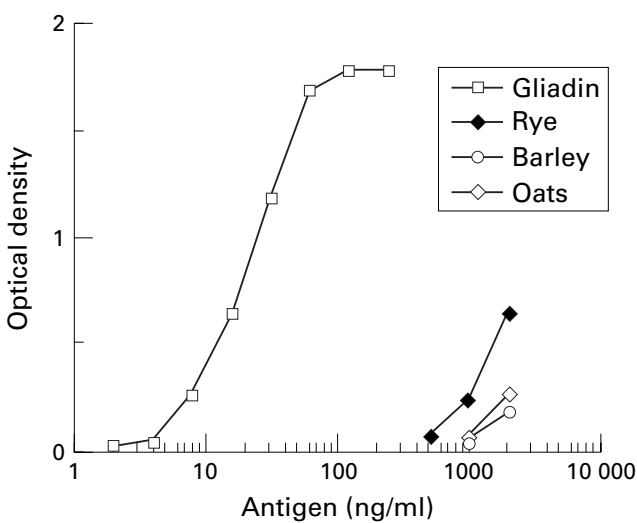

Figure 1 Standard curve for wheat gliadin and curves for prolamins of rye, barley, and oats.

PREPARATION OF ANTIGENS

Gliadins

Whole gliadin and its $\alpha, \beta, \gamma$, and $\omega$ subfractions were prepared as described previously from Kolibri wheat flour. ${ }^{10}$ The subfractions did not however conform to the classification proposed by Autran et al, ${ }^{11}$ based on $\mathrm{N}$-terminal amino acid sequences. Rector strain gliadin was provided by Dr $\mathrm{H}$ Wieser, and was prepared as described, except that $60 \%$ ethanol was used for extraction instead of $70 \% .^{12}$ The standard gliadin preparation was also obtained from a commercial kit for measurement of gluten (Transia Ltd, Lyon, France). No information is given by the manufacturers as to the strain of wheat used. Forty per cent ethanolic solutions of each gliadin standard were prepared at 1 $\mathrm{mg} / \mathrm{ml}$. These were then further diluted in water to $100 \mu \mathrm{g} / \mathrm{ml}$. Solutions were centrifuged at $6500 \mathrm{~g}$ for 10 minutes to precipitate any gliadin which might have come out of solution following lowering of the ethanol concentration. Solutions were then analysed by the method of Lowry et al, ${ }^{13}$ against bovine serum albumin (BSA) as a standard, and by absorbance at $280 \mathrm{~nm}$ under ultraviolet light. Standard solutions of gliadin $2000 \mathrm{ng} / \mathrm{ml}$, according to the Lowry reaction, were made up in $5 \%$ BSA with $0.1 \%$ sodium azide and stored in aliquots at $-20^{\circ} \mathrm{C}$.

\section{Other prolamins}

The flours of rye (variety Rheidol), barley (variety Porter), and oats (variety Peniarth) were obtained from Plant Breeding International, Trumpington, Cambridge. Prolamins were extracted at $50 \mathrm{mg} / \mathrm{ml}$ in $50 \%$ ethanol by mixing for two hours at room temperature. Additionally the pure prolamins from oats (variety Alfred) were kindly supplied by $\mathrm{Dr} \mathrm{H}$ Wieser. ${ }^{14}$

Table 1 Sensitivity of the assay to coeliac toxic prolamins

\begin{tabular}{lll}
\hline Protein & Sensitivity & Equivalent in flour \\
\hline Gliadin & $4 \mathrm{ng} / \mathrm{ml}$ & $0.008 \mathrm{mg} / 100 \mathrm{~g}$ \\
$\alpha$ gliadin & $4 \mathrm{ng} / \mathrm{ml}$ & $0.008 \mathrm{mg} / 100 \mathrm{~g}$ \\
$\beta$ gliadin & $16 \mathrm{ng} / \mathrm{ml}$ & $0.032 \mathrm{mg} / 100 \mathrm{~g}$ \\
$\gamma$ gliadin & $16 \mathrm{ng} / \mathrm{ml}$ & $0.032 \mathrm{mg} / 100 \mathrm{~g}$ \\
$\omega$ gliadin & $1000 \mathrm{ng} / \mathrm{ml}$ & $2 \mathrm{mg} / 100 \mathrm{~g}$ \\
Rye & $500 \mathrm{ng} / \mathrm{ml}$ & $1 \mathrm{mg} / 100 \mathrm{~g}$ \\
Barley & $1000 \mathrm{ng} / \mathrm{ml}$ & $2 \mathrm{mg} / 100 \mathrm{~g}$ \\
Oats & $1000 \mathrm{ng} / \mathrm{ml}$ & $2 \mathrm{mg} / 100 \mathrm{~g}$ \\
\hline
\end{tabular}

Polymeric prolamins

Low molecular weight glutenins were obtained from Dr P Payne at Plant Breeding International. ${ }^{15}$ These were similarly made into solutions of $2000 \mathrm{ng} / \mathrm{ml}$ Lowry positive protein and stored as above.

PREPARATION OF FOODSTUFFS

Wheat starches-Eight wheat starches were analysed, of which four were commercial brands (Nutregen, Wheatex, Glutafin, and Kinderm). Four were experimental starches obtained from the manufacturer of the Juvela brand (AB Semper, Stockholm) who provided Kjeldahl nitrogen analysis, from which we calculated total protein by using the factor 5.7.

Non-gluten foods-The following foods frequently used as additives and substitutes in gluten-free foods were tested in the assay: dried skimmed milk powder (Premier Brands, Staffs); sugar beet bran (Nutricia Dietary Products), soya flour (Community Foods, Brent Cross, London), chick pea flour (Ethos Health Foods, Nottingham), and gluten-free maize flour (Cantassium Food Company, Putney). Whole grains of rice, millet, and sorghum were kindly donated by Dr P Janssen of the regional food inspection service, Zuppen, The Netherlands. Pure grains of 15 varieties of wheat were obtained from AB Semper (Oslo). These were milled using a pestle and mortar.

Gluten-free products-At the request of Nutricia Dietary Products (Trowbridge, Wiltshire), one of the leading UK manufactures of glutenfree products, we analysed a variety of cooked and uncooked gluten-free products. A number of foods produced by a smaller company, Dr Schar (Postal, Italy) were also tested.

Cooked flour products-A test flour was spiked with $1 \mathrm{~g} / 100 \mathrm{~g}$ of Rector strain gliadin standard, formed into a dough, and baked at $230^{\circ} \mathrm{C}$ for 10 minutes. The loaf was separated into the crust and crumb fractions. These fractions were provided by Dr H Wieser.

All the above samples were extracted by stirring at $50 \mathrm{mg} / \mathrm{ml}$ in $40 \%$ ethanol for one hour at room temperature, after twice defatting the whole wheat products with four volumes of $n$-butanol. Additionally, a reducing buffer was prepared containing $50 \%$ aqueous propan-1ol, $1 \% \beta$ mercaptoethanol, Tris- $\mathrm{HCl} 0.08 \mathrm{~mol} / 1$ (pH 7.5), and $2 \mathrm{~mol} / 1$ urea. Cooked crust and crumb fractions were extracted in this buffer for one hour at $60^{\circ} \mathrm{C}$ under nitrogen. A set of gliadin standards was made up in a reducing buffer diluted 100-fold in phosphate buffered saline (PBS)/Tween.

DOUBLE SANDWICH ELISA

A double sandwich ELISA was performed using a modification of our previous method. ${ }^{16}$ Briefly, polyclonal rabbit anti-unfractionated gliadin $(50 \mu \mathrm{g} / \mathrm{ml})$ acted as a capture antibody. Standard curves were constructed for wheat gliadin, range $1-250 \mathrm{ng} / \mathrm{ml}$, and for rye secalin, barley hordein, and oat avenin over a range 1-2000 ng/ml. Extracts of food samples were diluted depending on the expected gliadin content as follows: neat and diluted 1/10 in 
Table 2 Foodstuffs which tested negative in the double

\begin{tabular}{l} 
Tropical cereals \\
Millet \\
Maize \\
Sorghum \\
Rice \\
Jawar \\
Legumes \\
Soya flour \\
Chick pea flour \\
Buckwheat \\
Quinoa \\
Miscellaneous \\
Potato flour \\
Molasses \\
Skimmed milk powder \\
Sugar beet fibre \\
\hline
\end{tabular}
sandwich ELISA

Sugar beet fibre

PBS/Tween, for samples of expected gliadin content zero; diluted $1 / 5$ to $1 / 160$ for wheat starches and $1 / 2000$ to $1 / 60000$ for whole wheats and breads. The samples and standards were incubated for one hour at room temperature, followed by murine PN3 monoclonal antibody, diluted 1/3000, for one hour and rabbit antimouse IgG conjugated to alkaline phosphatase diluted 1/300 (Sigma Chemicals, Poole, Dorset), for one hour. The substrate was $p$-nitrophenyl phosphate $1 \mathrm{mg} / \mathrm{ml}$ in diethanolamine buffer, $\mathrm{pH}$ 9.8, incubated for 30 minutes at room temperature. In a later set of experiments, incubation steps at all stages were reduced to 30 minutes.

Sensitivity - This was calculated as the lowest concentration of antigen which gave an optical density (OD) greater than 1.5 times the mean of six assay blanks (PBS/Tween in place of antigen). The amount of each prolamin detectable in a flour product was calculated with respect to the quantities of product extracted for use in this assay $(50 \mathrm{mg} / \mathrm{ml})$. If the sensitivity to a particular antigen was-for example, 15 $\mathrm{ng} / \mathrm{ml}$, then that quantity of antigen could be detected in $50 \mathrm{mg}$ of product. The sensitivity is expressed as mg of antigen per $100 \mathrm{~g}$ of product.

Repeatability - This was assessed by measuring the same two wheat starch extracts on three separate ELISA plates, on the same day, in parallel experiments. The coefficient of variation was calculated as follows: standard deviation $/$ mean $\times 100 \%$.

Table 3 Gliadin content of various wheat varieties

\begin{tabular}{lll}
\hline Name of strain & Type of wheat & Gliadin content \\
\hline Sverno & Soft spring & $6.0 \mathrm{~g} / 100 \mathrm{~g}$ \\
Ring & Soft spring & $1.2 \mathrm{~g} / 100 \mathrm{~g}$ \\
Dragon & Strong spring & $6.0 \mathrm{~g} / 100 \mathrm{~g}$ \\
Kadett & Strong spring & $4.5 \mathrm{~g} / 100 \mathrm{~g}$ \\
Rang & Soft spring & $6.0 \mathrm{~g} / 100 \mathrm{~g}$ \\
Draband & Soft spring & $5.0 \mathrm{~g} / 100 \mathrm{~g}$ \\
Pompe & Soft spring & $4.0 \mathrm{~g} / 100 \mathrm{~g}$ \\
Holme & Autumn strong & $5.0 \mathrm{~g} / 100 \mathrm{~g}$ \\
Starke & Autumn strong & $5.0 \mathrm{~g} / 100 \mathrm{~g}$ \\
Folke & Autumn soft & $5.3 \mathrm{~g} / 100 \mathrm{~g}$ \\
Hilder & Autumn soft & $8.4 \mathrm{~g} / 100 \mathrm{~g}$ \\
Portal & Autumn soft & $9.0 \mathrm{~g} / 100 \mathrm{~g}$ \\
Solid & Autumn soft & $6.0 \mathrm{~g} / 100 \mathrm{~g}$ \\
Kosack & Autumn soft & $4.5 \mathrm{~g} / 100 \mathrm{~g}$ \\
Dinkle & Spelt $($ Triticum spelta $)$ & $5.9 \mathrm{~g} / 100 \mathrm{~g}$ \\
\hline
\end{tabular}

All wheat varieties have been used for food purposes. Strong wheats have been used for bread making, soft varieties for other bakery products. All except Dinkle are varieties of Triticum aestivum.

Table 4 Protein and gliadin content of experimental wheat starches (provided by $A B$ Semper)

\begin{tabular}{|c|c|c|c|c|c|}
\hline \multirow{2}{*}{$\begin{array}{l}\text { Starch } \\
\mathrm{A}\end{array}$} & \multirow{2}{*}{$\begin{array}{l}\text { Protein Kjeldahl N×5.7 } \\
0.1995 \%\end{array}$} & \multicolumn{3}{|c|}{ Gliadin $\mathrm{mg} / 100 \mathrm{~g}$ ( 3 analyses) } & \multirow{2}{*}{$\begin{array}{l}\text { Mean } \\
0.57\end{array}$} \\
\hline & & 0.10 & 0 & 1.60 & \\
\hline $\mathrm{B}$ & $0.1995 \%$ & 1.12 & 0.76 & 2.70 & 1.52 \\
\hline $\mathrm{C}$ & $0.2132 \%$ & 2.40 & 2.80 & 6.00 & 3.73 \\
\hline $\mathrm{D}$ & $0.2286 \%$ & 7.70 & 7.70 & 7.00 & 7.40 \\
\hline
\end{tabular}

Table 5 Gliadin content of commercial wheat starches

\begin{tabular}{llll}
\hline Trade name & Gliadin $m g / 100 \mathrm{~g}$ (2 analyses) & Mean \\
\hline Kinderm & 6.50 & 7.80 & 7.20 \\
Glutafin & 0.50 & 0.50 & 0.50 \\
Wheatex & 1.00 & 1.00 & 1.00 \\
Nutregen & 8.00 & 7.50 & 7.75 \\
\hline
\end{tabular}

Reproducibility-This was calculated by comparing three extracts of the two wheat starches, and measuring these on three consecutive days. The coefficient of variation was calculated as above. Both of these assays were performed using the shortened form of the assay-that is, 30 minute incubations at each stage.

\section{EPITOPE IDENTIFICATION}

ELISA plates were coated overnight with avidin $10 \mu \mathrm{g} / \mathrm{ml}$ (Sigma Chemicals). Dilution curves of biotinylated 19-mer peptide and biotinylated point substitutions were incubated, followed by monoclonal antibody PN3 $(1 / 2500)$ The assay was developed as described above.

\section{Results}

MEASUREMENT OF GLIADIN BY DOUBLE

SANDWICH ELISA

Sensitivity

The sensitivity for unfractionated gliadin was 4 $\mathrm{ng} / \mathrm{ml}$ - that is, an absolute sensitivity of $200 \mathrm{pg}$ or $0.008 \mathrm{mg} / 100 \mathrm{~g}$ flour (fig 1 ). Table 1 shows the sensitivity of the assay for various prolamin fractions. Both varieties of oat prolamins were detected in the assay.

Non-gluten foodstuffs

Extracts of rice, maize, millet, sorghum flours, and miscellaneous ingredients used in glutenfree foods all tested negative (see table 2).

Whole wheats

Fifteen varieties of wheat had total gliadin contents in the range 1.2 to $9 \mathrm{~g} / 100 \mathrm{~g}$ of whole grains (table 3 ).

Wheat starches

All had detectable gliadin, ranging from 0.50 to $7.75 \mathrm{mg} / 100 \mathrm{~g}$ (tables 4 and 5).

Commercially available gluten free foods

Table 6 shows the gliadin content of gluten-free products. Values obtained range from 0 to 6.7 $\mathrm{mg} / 100 \mathrm{~g}$.

\section{Cooked products}

The gliadin content of whole flour was 4.16 $\mathrm{g} / 100 \mathrm{~g}$; that of the resultant crumb and crust, extracted with $40 \%$ ethanol, was 1.68 and 0.7 $\mathrm{g} / 100 \mathrm{~g}$, respectively - that is, $17 \%$ of the value for uncooked flour. Using reducing conditions, the gliadin content of the crumb was $2 \mathrm{~g} / 100 \mathrm{~g}$, and of the crust $1.2 \mathrm{~g} / 100 \mathrm{~g}$. Gliadin standards made up in a 100-fold dilution of reducing buffer produced an attenuated standard curve, such that a standard of gliadin content $62 \mathrm{ng} / \mathrm{ml}$, appeared to contain only $16 \mathrm{ng} / \mathrm{ml}$, a $74 \%$ reduction.

\section{Standards}

Figure 2 shows the standard curves obtained for gliadins of different varieties. Rector and commercial standard gliadins produced similar parallel curves to that obtained for Kolibri gliadin. A sample with optical density 
Table 6 The gliadin content of gluten-free food products

\begin{tabular}{|c|c|}
\hline Product & Gliadin $\mathrm{mg} / 100 \mathrm{~g}$ \\
\hline \multicolumn{2}{|l|}{ Wheat starch based products } \\
\hline \multicolumn{2}{|l|}{ Cooked foods ${ }^{\star}$} \\
\hline Glutafin GF fibre loaf & 0.128 \\
\hline Glutafin GF white bread with soya & 0.200 \\
\hline Loprofin white bread (with salt, canned) & 0.16 \\
\hline Loprofin white bread (no added salt, canned) & 0.12 \\
\hline Low protein $\mathrm{dp}$ chocolate chip cookies & 0.24 \\
\hline \multicolumn{2}{|l|}{ Uncooked products } \\
\hline Glutafin GF white mix & 0.9 \\
\hline Glutafin GF fibre mix & 0.9 \\
\hline Rite Diet low protein flour mix & 0 \\
\hline Loprofin low protein mix & 1.4 \\
\hline \multicolumn{2}{|l|}{ Wheat-free products } \\
\hline \multicolumn{2}{|l|}{ Cooked products $\dagger$} \\
\hline Rite Diet GF chocolate digestive biscuits & 0.184 \\
\hline Rite Diet GF custard creams & 1.18 \\
\hline Glutafin GF tea biscuits & 0.21 \\
\hline Glutafin GF crackers & 0.144 \\
\hline Glutafin GF biscuits & 0.35 \\
\hline Glutafin GF digestive biscuits & 0.152 \\
\hline Loprofin orange flavour cream wafers & 0.144 \\
\hline Rite Diet GF mince pies & 1.28 \\
\hline \multicolumn{2}{|l|}{ Uncooked products $\ddagger$} \\
\hline Glutafin pasta spirals & 6.7 \\
\hline Glutafin pasta spirals & 0.56 \\
\hline Glutafin vermicelle & 3.7 \\
\hline Glutafin vermicelle & 0.07 \\
\hline Glutafin spaghetti & 2.2 \\
\hline Glutafin spaghetti & 5.44 \\
\hline Glutafin macaroni penne & 3.6 \\
\hline Glutafin macaroni penne & 0.3 \\
\hline Glutafin macaroni & 0.5 \\
\hline \multicolumn{2}{|l|}{ Products made by Dr Schar (Italy): all wheat-free } \\
\hline \multicolumn{2}{|l|}{ Uncooked products } \\
\hline Penne & 0 \\
\hline Pasta Alfabeto & 0.028 \\
\hline Capelli d'Angello & 0.014 \\
\hline Spaghetti & 0 \\
\hline Pipette & 0 \\
\hline \multicolumn{2}{|l|}{ Cooked products } \\
\hline GF biscuits & 1.6 \\
\hline Snack GF chocolate wafers with hazelnut & 0 \\
\hline GF biscuits with chocolate & 0.3 \\
\hline GF hazelnut wafers & 0 \\
\hline GF cocoa wafers & 0 \\
\hline GF vanilla wafers & 0.6 \\
\hline
\end{tabular}

* Other wheat starch containing cooked products listed below contained less than $0.1 \mathrm{mg} / 100 \mathrm{~g}$ : Loprofin chocolate chip cookies, Glutafin GF white loaf, Rite Diet GF white rolls, Rite Diet GF white bread, Rite Diet GF fibre rolls, Rite Diet low protein white bread with added fibre, Loprofin LP white rolls, Loprofin LP loaf.

† Other wheat-free cooked products listed below contained less than $0.1 \mathrm{mg} / 100 \mathrm{~g}$ : Glutafin GF WF white rolls, Glutafin GF WF white loaf, Nutricia Erma WF white bread, Rite Diet GF gingernut cookies, Rite Diet GF chocolate chip cookies, Rite Diet GF bourbon, Loprofin crackers, Loprofin chocolate flavour cream biscuit, Loprofin vanilla flavour cream wafers, dp butterscotch cookies, Loprofin chocolate flavour cream wafers, GF dietary GF thin wafers, Glutafin magdalens, Glutafin chocolate snack, Zonnatura snack wafels, Zonnatura rijstwafels, Zonnatura carobean, Rijstwafels, Zonnatura puffed rice cereal, Glutafin chocolate cake, Rite Diet banana cake, Rite Diet date and walnut cake, Rite Diet lemon cake, Rite Diet GF Christmas pudding, Rite Diet GF rich fruit cake.

¥ Other wheat-free uncooked products listed below contained less than $0.1 \mathrm{mg} / 100 \mathrm{~g}$ : Glutafin tagliatelle, Glutafin GF multigrain fibre mix, Glutafin GF multigrain white mix, Rite Diet GF white bread mix, Rite Diet GF brown bread mix, Rite Diet GF flour mix, Rite Diet GF/WF baking powder, Loprofin egg replacer, Loprofin PKU milk, Sesame crunch, Loprofin tagliatelle, Loprofin spirals pasta, Loprofin spaghetti, Zilversliesrijst, Quinoa, Gierst millet, Zonnatura linzen lentils.

1.0 would appear to have a gliadin content of $60 \mathrm{ng} / \mathrm{ml}$ against Rector gliadin, $70 \mathrm{ng} / \mathrm{ml}$ against Kolibri gliadin (used in our experiments), and $100 \mathrm{ng} / \mathrm{ml}$ against commercial standard.

\section{Storage and stability}

Storage of the gliadin standard solution for five years at $-20^{\circ} \mathrm{C}$ led to a decrease in immunogenicity so that a sample with OD 1.0 would have an apparent gliadin content of $22 \mathrm{ng} / \mathrm{ml}$ when measured against the new standard, but $50 \mathrm{ng} / \mathrm{ml}$ against the old standard. Exposing the concentrated purified antibody solution to nil, one, and two freeze/thaw cycles did not lead to any decrease in activity.

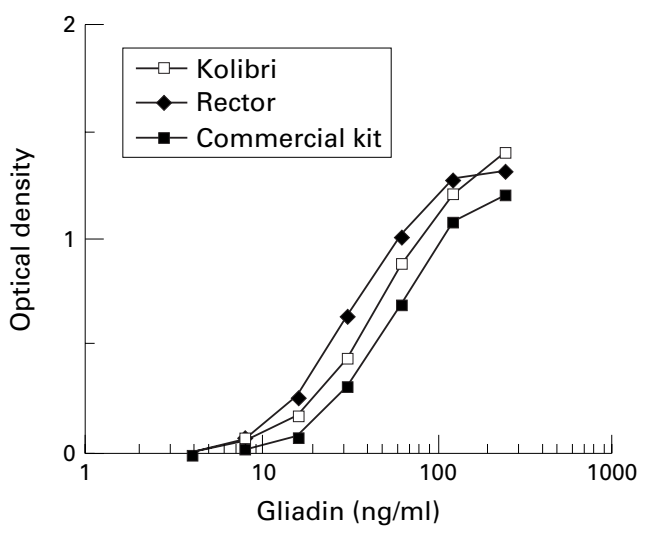

Figure 2 Standard curves for gliadin from three varieties of wheat.

\section{Shorter incubation times}

These did not decrease the sensitivity of the assay, which remained at $4 \mathrm{ng}$ gliadin $/ \mathrm{ml}$.

\section{Repeatability}

Assays employed the shorter incubation times. Values for the first starch extract were 1.44, 1.20 , and $1.28 \mathrm{mg} / 100 \mathrm{~g}$ (coefficient of variation $9.3 \%$ ). Values for the second starch extract were $3.20,3.04$, and $3.60 \mathrm{mg} / 100 \mathrm{~g}$ (coefficient of variation $8.7 \%$ ).

\section{Reproducibility}

Values for the first starch extract were 1.20, 1.66 , and $1.73 \mathrm{mg} / 100 \mathrm{~g}$ (coefficient of variation $18.8 \%$ ). Values for the second starch extract were $3.04,4.80$, and $4.30 \mathrm{mg} / 100 \mathrm{~g}$ (coefficient of variation $22.3 \%$ ).

IDENTIFICATION OF THE EPITOPE RECOGNISED BY THE ANTIPEPTIDE MONOCLONAL ANTIBODY Substitution of amino acids Q (33), P (36), and $\mathrm{P}$ (38) greatly reduced the binding of PN3 to native peptide, suggesting that the epitope of importance may be in the region of the sequence QQQPFP. Other substitutions had no effect.

\section{Discussion}

Our assay is 1000 -fold more sensitive to gliadin than will be required for the proposed new WHO-Codex regulations. The similarity of the standard curves produced by the assay for three standard gliadin preparations, and the cross reaction of 15 strains of wheat flour suggest that the epitope measured is widely distributed among wheat gliadin varieties. The epitope in the region of QQQPFP, recognised by our monoclonal antibody, is found in $\alpha$ and $\omega$ type gliadins. Avenins contain QQQPF, while the lesser motifs QQQP and QQPFP are found in $\gamma$ type gliadins, hordeins, and secalins. ${ }^{8}$ The low sensitivity of the assay to $\omega$ gliadins is probably due to the low reactivity of polyclonal antigliadin antiserum to $\omega$ gliadins. ${ }^{17}$

Whether measurement of this epitope allows a true assessment of gliadin concentration is a more difficult question. Wheat flour, depending on its strength, contains 3.0 to $7.5 \mathrm{~g} / 100 \mathrm{~g}$ gliadin - that is, $40 \%$ of the total protein. The majority of our measurements for whole flours were within this range. 
Wheat starch samples obtained from the manufacturers of the Juvela brand (AB Semper Stockholm) were available, with Kjeldahl nitrogen analysis. All fell within the current limit of $0.3 \%$ total protein, and within the proposed limit of $10 \mathrm{mg}$ gliadin $/ 100 \mathrm{~g}$. The relation of total protein to gliadin content varies for different wheat starches. Up to $0.25 \%$, most protein consists of starch granule protein; over $0.25 \%$, any increase in protein content is entirely gliadin. ${ }^{2}$ In a series of 16 wheat starches, five samples of $0.2-0.3 \%$ protein had a gliadin content of approximately $5 \mathrm{mg} / 100 \mathrm{~g}$. Our experimental wheat starches had protein contents of $0.2-0.23 \%$; thus gliadin measurements of $0.57,1.52,3.73$, and 7.4 appear reasonable estimates in the light of the data of Skerritt and Hill. ${ }^{2}$ However, individual starches may vary considerably from mean values of protein to gliadin content.

We also assessed four commercially available starches. Kinderm, Glutafin, and Wheatex starches are currently available, comply with the current regulations, contain less than $0.3 \%$ protein, and do not, to our knowledge, induce symptoms in most patients. Using our assay these starches would also comply with the proposed new regulations. Nutregen wheat starch was withdrawn from the market some years ago because it contained more than $0.3 \%$ protein. Our assay found only an acceptable level, 8 $\mathrm{mg} / 100 \mathrm{~g}$ gliadin in this product; thus we may underestimate the gliadin content of some wheat starches.

In order to measure accurately gliadin in wheat starches, it is essential that the standard is of the same composition as the sample. However, since our standard is whole gliadin and wheat starches comprise those proteins which remain after washing, differing solubilities of the subfractions may profoundly influence the measurement of gliadin. Repeated washing with water of wheat starches under laboratory conditions leads to a stripping of the $\alpha$ and $\omega$ gliadins from the surface of the starch granules, whereas the $\gamma$ gliadins are retained longer (Donald D Kasarda, personal communication). It is possible that $\gamma$ gliadins may be more highly represented in a washed wheat starch than the other gliadins. This alteration of composition might account for some results being lower than expected. However this problem would emerge in any assay of this type where unfractionated gliadin is used as the standard.

Our assay detects rye and barley prolamins, but at much lower sensitivity than wheat; however, they could be estimated quantitatively if the appropriate antigen was used as a standard curve. Rye or barley flours analysed against gliadin standards would register as not glutenfree, having $54 \mathrm{mg} / 100 \mathrm{~g}$ and $16.5 \mathrm{mg} / 100 \mathrm{~g}$ of "gliadin".

Careful feeding studies have suggested that oat prolamins are not coeliac toxic. ${ }^{18}$ However, in vitro studies have shown activation of intestinal cell mediated immunity by oat prolamins ${ }^{19}$; the subject therefore remains to be clarified. Two samples of pure strain oat prolamins cross reacted at low levels in our assay, depending on the source. This suggests genuine cross reactivity of oat prolamins with gliadin, as opposed to wheat contamination during cultivation, milling, or storage. Whole oat flour gave an apparent gliadin content of $34.6 \mathrm{mg} / 100 \mathrm{~g}$ and would register as unacceptable. Our monoclonal, PN3, raised against a peptide of known coeliac enterotoxicity, recognises an epitope in the region of the motif QQQPFP. The motif QQQPF occurs within oat prolamins, ${ }^{8}$ and this may confer the cross reactivity with PN3. However, T cell antigenicity may involve a different or larger motif within the gliadin peptide. Studies of T cell antigenicity and HLA class II binding of gliadin peptides $^{2021}$ may help to elucidate minimal epitopes for coeliac toxicity and should establish the role of oat prolamins in coeliac disease.

The coeliac toxicity of glutenin subunits is unknown. Low molecular weight subunits have a similar amino acid composition to gliadin and cross reacted in our assay. These proteins contain the motif QQQP, hence their reactivity with PN3; whether this sequence confers toxicity is unknown.

Our assay does not give quantitative results for cooked foods. Use of reducing agents prior to extraction proved unsuccessful. The sensitivity of the standard curve was attenuated, presumably due to the denaturation of the capture antibody. Steps could be taken to remove reducing agents; however the methodology is not suitable for use as a fast routine test in a small scale quality control laboratory. A kit, measuring $\omega$ gliadin, ${ }^{22}{ }^{23}$ the heat stable fraction, attempted to circumvent these problems, but has received mixed reviews. ${ }^{24} \omega$ Gliadins may comprise $6-20 \%$ of the total gliadins, depending on strain, leading to potential errors of $-44 \%$ to $+80 \%$ when extrapolating total gliadin from $\omega$ gliadin content. ${ }^{25}$ We suggest that there is no ideal method for measurement of gliadin in cooked foods.

We employed our assay to screen some of the gluten-free products made by Nutricia Dietary Products. While traces of gliadin could be detected in the majority of wheat starch based products, the highest was for Loprofin low protein mix, at $1.4 \mathrm{mg} / 100 \mathrm{~g}$; this is not however available on presciption for gluten sensitive enteropathy.

The cooked products are more difficult; only $17 \%$ of the gliadin in flour was measurable in the outer crust of a loaf of bread. Assuming our assay measures only $15 \%$ of the actual gluten content, all products would fall well within permissible levels. The majority of the wheatfree products contain no or only a trace of gliadin, even allowing for the possibility that only $15 \%$ of gliadin was detected. The assay however highlighted some issues. For example, Rite Diet mince pies with $1.28 \mathrm{mg} / 100 \mathrm{~g}$ and Rite Diet custard creams with $1.18 \mathrm{mg} / 100 \mathrm{~g}$, are both cooked and therefore might contain up to 8.53 and $7.87 \mathrm{mg}$ gliadin $/ 100 \mathrm{~g}$ respectively. Similarly some of the uncooked pasta samples contained up to $6.7 \mathrm{mg} / 100 \mathrm{~g}$ gliadin. All of these products however contained than less $10 \mathrm{mg}$ gliadin $/ 100 \mathrm{~g}$, and therefore comply with current guidelines for 
gluten-free foods. Examination of different batches of pasta revealed variation, with, in one case, no gliadin detected, suggesting the potential for contamination during processing. Subsequent changes in working practice by the company have lead to production of sequential batches of pasta products in which negligible quantities of gliadin were detected.

Analysis of products from a smaller European manufacturer showed that-for example, gluten-free biscuits made from flours of maize, tapioca, and soya flour contained $1.6 \mathrm{mg}$ gliadin $/ 100 \mathrm{~g}$. This might represent only $15 \%$ of the gliadin content in the uncooked product, which could potentially be $10.7 \mathrm{mg} / 100 \mathrm{~g}$.

These data suggest that our assay is effective in detecting gliadin in gluten-free foods. In the case of cooked products extrapolation can give an approximate idea of gliadin content.

The assay described here is robust and repeatable with a coefficient of variation of less than $10 \%$. The reproducibility was less good: a coefficient of variation of $20 \%$ is usually the maximum tolerated for this type of assay; our measurements were just above and just below this. Further standardisation will be required.

In conclusion, we feel that this assay may form the basis of a sensitive method for measurement of gluten in foods based on wheat, rye, barley, and oats.

The authors wish to thank the Ministry of Agriculture, Fisheries and Food, AB Semper, Nutricia Research Foundation, The European Starch Association, St Thomas's Research (Endowments) Committee, The National Institute of Health (Gran number R01DK47716), and the Jean Shanks Research Foundation for their support. We are also very grateful to
Herbert Wieser and Dr Donald D Kasarda for their advice.

1 Howdle PD, Losowsky MS. Review of methods for measuring gliadins in food. Gut 1990;31:712-13.

2 Skerritt J, Hill A. How "free" is "gluten-free"? Relationship between Kjeldahl nitrogen and gluten protein content for wheat starches. Cer Chem 1992;69:110-12.

3 Holmes GKT, Prior P, Lane MR, et al. Malignancy in coeliac disease: the effect of a gluten-free diet. Gut 1989;30 333-8.

4 Codex Alimentarius Commission. Standards for gluten-free foods. Rome: FAO/WHO, 1981:118.

5 Windermann H, Fritschy F, Baumgartner E. Enzyme linked immunosorbent assay for wheat $\alpha$-gliadin and whole immunosorbent assay for wheat $\alpha$-gliadin 2 .
gliadin. Biochim Biophys Acta 1982;709:110-21.
6 Friis SU. Enzyme-linked immunosorbent assay for quantitation of cereal proteins in coeliac disease. Clin Chim Acta tion of cereal protein

7 Sturgess RP, Day P, Ellis HJ, et al. Wheat peptide challenge in coeliac disease. Lancet 1994;343:758-61.

8 Shewry P, Tatham A, Kasada D. Cereal proteins and coeliac disease. In: Marsh M, ed. Coeliac disease. Oxford: Blackwell Scientific Publications, 1992:305-48.

9 Ellis HJ, Doyle AP, Wieser H, et al. Specificities of monoclonal antibodies to domain 1 of $\alpha$-gliadins. Scand $\mathcal{F}$ Gastroenterol 1993;28:212-16.

10 Ciclitira PJ, Evans DJ, Fagg NLK, et al. Clinical testing of gliadin fractions in coeliac patients. Clin Sci 1984;66:35764 .

11 Autran J-C, Lew EJ-L, Nimmo CC, et al. N-terminal amino acid sequencing of prolamins from wheat and related species. Nature 1979;282:527-9.

12 Wieser H, Modi A, Selimeier W, et al. High-performance liquid chromatography of gliadins from different wheat varieties: amino acid composition and $\mathrm{N}$-terminal amino acid sequence of components. $Z$ Lebensm Unters Forsch 1987; 185:371-8.

13 Lowry OH, Rosebrough NJ, Farr AL, et al. Protein measurement with the folin phenol reagent. F Biol Chem 1951;193:265-75.

14 Wieser H, Belitz H-D. Amino acid compositions of avenins separated by reversed-phase high-performance liquid chromatography. 7 Cer Sci 1989;9:221-6.

15 Payne PI, Cornfield KG. Subunit composition of wheat glutenin proteins, isolated by gel filtration in a dissociating medium. Planta 1979;145:83-8.

16 Ellis HJ, Doyle AP, Wieser H, et al. Measurement of gluten using a monoclonal antibody to a sequenced peptide of $\alpha$-gliadin from the coeliac activating domain I. F Biochem Biophys Method 1994;28:77-82.

17 Ciclitira PJ, Ellis HJ. Relationship of antigenic structure of cereal proteins to their toxicity in coeliac patients. Brf Nutr 1985;53:39-45.

18 Janthuinen E, Pikkarainen $\mathrm{P}$, Kemppainen $\mathrm{T}$, et al. A comparison of diets with and without oats in adults with comparison of diets with and without oats in

19 Leone NA, Mazzarella G, Ciacci C, et al. Oats prolamins in vitro activate intestinal cell mediated immunity in coeliac disease. In: Collin P, Maki M, eds. Seventh International Symposium on Coeliac Disease, 5-7 September 1996, Tampere, Finland. Lege Artis, 1996:69.

20 Shidrawi RG, Parnell NDJ, Ciclitira PJ, et al. Binding of gluten derived peptides to the HLA DQ $\left(\alpha^{\star} 0501, \beta^{\star} 0201\right)$ molecule assessed in a cellular assay. Clin Exp Immunol 1998;111:158-65.

21 Johansen $\mathrm{BH}$, Gjertsen $\mathrm{HA}$, Vartdal $\mathrm{H}$, et al. Binding of peptides from the $\mathrm{N}$-terminal region of $\alpha$-gliadin to the celiac disease associated HLA-DQ2 molecule assessed in biochemical and T cell assays. Clin Immunol Immunopathol 1996;79:288-93.

22 Skerritt JH, Hill AS. Self-management of dietary compliance in coeliac disease by means of ELISA "home test" to detect gluten. Lancet 1991;337:379-81.

23 Skerritt JH, Hill AS. Enzyme-immunoassay for determination of gluten in foods; collaborative study. F Assoc Off Anal Chem 1991;74:257-64.

24 Booth CC, Losowsky MS, Walker-Smith JA, et al. Inter-laboratory variation in gluten detection by ELISA kit. Lancet 1991;337:1094.

25 Wieser H, Seilmeier W, Belitz H-D. Quantitative determination of gliadin subgroups from different wheat varieties. J Cer Sci 1994;19:149-55. 